\title{
SIGNIFICANCE OF URINARY HYDROXYPROLINE IN MAN
}

\author{
By DARWIN J. PROCKOP AND ALBERT SJOERDSMA \\ (From the Section of Experimental Therapeutics, National Heart Institute, Bethesda, Md.)
}

(Submitted for publication September 27, 1960; accepted January 12, 1961)

Since nearly all of the hydroxyproline of the body is found in collagen, it has been suggested $(1,2)$ that the urinary excretion of this imino acid may be an important index of collagen metabolism. The origin of urinary hydroxyproline, however, is not definitely established. The isotopic studies of Stetten (3) in rats indirectly suggested that most of the free and peptide hydroxyproline in the body arises from the breakdown of collagen, since she found that hydroxyproline- $\mathrm{N}^{15}$ was not significantly incorporated into collagen. Ziff, Kibrick, Dresner and Gribetz (1), on the other hand, observed an increased excretion of hydroxyproline when it was added to the diet of human subjects, in the form of gelatin. Although Ziff and co-workers did not emphasize this point, their results suggested the possibility that under normal conditions much of urinary hydroxyproline may originate from dietary proteins.

The present study was undertaken to investigate further the factors that influence hydroxyproline excretion in man. Although ingestion of large amounts of gelatin was found to increase urinary hydroxyproline, its urinary excretion did not decrease when hydroxyproline was eliminated from the normal diet, or even if subjects were placed on a protein-free diet. No diurnal variation in urinary hydroxyproline was found, and hydration or dehydration did not alter excretion. Ingestion of large amounts of hydroxyproline as the free imino acid resulted in an increased excretion of free, but not of bound hydroxyproline, the peptide form which normally accounts for nearly all of the hydroxyproline in urine.

These findings indicate that the daily excretion of hydroxyproline is largely independent of factors that influence the excretion of other amino acids, and they support the suggestion that urinary hydroxyproline arises from the breakdown of body collagen. The results are consistent with the hypothesis that the large hydroxyproline excretions found in children (1) and in some cases of Marfan's syndrome (2) reflect a rapid rate of collagen degradation.

An incidental discovery in the study was that the increase in urinary hydroxyproline after ingestion of gelatin represents an increased excretion of hydroxyproline peptides. This appears to be the first demonstration that significant amounts of peptides can be excreted following ingestion of a protein.

\section{MATERIALS AND METHODS}

The 8 subjects utilized in the study were hospitalized for periods of 3 to 12 weeks ; 3 were patients with Marfan's syndrome, 2 of whom were previously shown to have elevated excretions of hydroxyproline (2). The remaining 5 were normal adult volunteers -2 males and 3 females.

Procedures. Urine specimens were collected daily under $30 \mathrm{ml}$ toluene and stored at $0^{\circ} \mathrm{C}$ for periods up to 1 year. It was found that, in the absence of preservative, hydroxyproline was converted from the peptidebound to the free form in normal urine, and that hydroxyproline disappeared rapidly in urines containing large amounts of the free imino acid. For the first 5 days after admission, the subjects were placed on an ad lib. diet, but thereafter they were maintained on a diet low in hydroxyproline. In some subjects, after 3 weeks had elapsed on this diet, oral supplements of various amino acids and proteins were administered on alternate days. Urine from the previous day was used as a control in each case. Each dietary supplement was given in $250 \mathrm{ml}$ of orange juice at the beginning of a urine collection period, and the subjects were kept in a fasting state for 8 hours before and 4 hours after each administration. In a few instances the unpleasant taste of the supplements necessitated administration by gastric tube.

Diets and dietary supplements. The low hydroxyproline diet was similar to the one described by Ziff and associates (1) and provided 1,800 to 2,300 calories per day with 70 to $90 \mathrm{~g}$ protein, 200 to $300 \mathrm{~g}$ carbohydrate and 80 to $90 \mathrm{~g}$ fat, but no gelatin-containing foods such as meat, fish, Jell-o, soft candy or ice cream. It was estimated to contain less than $100 \mathrm{mg}$ hydroxyproline per day. The low protein diet was prepared daily by mixing $150 \mathrm{~g}$ of sucrose and $150 \mathrm{~g}$ of melted butter into $300 \mathrm{ml}$ of warm water and then adding the mixture to a thin paste made from $20 \mathrm{~g}$ of flour and water. Since the flour was the only nitrogen-containing constituent, and 
since flour contains negligible amounts of hydroxyproline (4), the diet was essentially free of hydroxyproline. It provided 1,750 calories per day distributed as $120 \mathrm{~g}$ fat, $165 \mathrm{~g}$ carbohydrate and $3 \mathrm{~g}$ protein.

The various amino acids were purchased from Nutritional Biochemicals Corp. All were $\mathrm{L}$ isomers except that DL forms of serine, threonine and valine were used in preparation of the mixture of amino acids found in gelatin (5). The gelatin was obtained from a commercial source. The casein hydrolysate (Casamino Acids) was from Difco Laboratories, and analysis showed that it contained less than 0.04 per cent hydroxyproline.

Urinary assays. Initially, urinary hydroxyproline was measured by the method of Mitoma and co-workers (6), but subsequent determinations were by a new procedure described elsewhere (7). From 0.1 to $4 \mathrm{ml}$ of untreated urine containing 5 to $50 \mu \mathrm{g}$ of hydroxyproline was used to measure free hydroxyproline. An equivalent amount of hydrolyzed urine was used to determine total hydroxyproline, which was considered to be the sum of free and peptide-bound hydroxyproline.

Urinary total nitrogen was measured by a microKjeldahl method (8), and $\alpha$-amino nitrogen by the method of Troll and Cannan (9).

\section{RESULTS}

The normal subjects on the study excreted from 16 to $34 \mathrm{mg}$ of hydroxyproline per day, and the three patients with Marfan's syndrome excreted from 38 to $90 \mathrm{mg}$ per day when on an $a d$ lib. diet (Table I). In agreement with the results of Ziff and colleagues (1), the free hydroxyproline was less than 3 per cent of the total excretion and in most instances was too small to measure accurately (less than $0.5 \mu \mathrm{g}$ per $\mathrm{ml}$ of urine).

Effect of restricting dictary hydroxyproline and total protcin intake. After 5 days on an ad lib. diet, three normal subjects and three patients with Marfan's syndrome were placed on the low hydroxyproline diet for periods of 3 to 6 weeks. At the end of this time there was no significant change in their hydroxyproline excretions (Table I). The moderate increase in the case of K.L. may be related to a weight loss of $3 \mathrm{~kg}$ sustained over the 3 week period (10); he found the low hydroxyproline diet unpalatable. Similarly, the decrease of hydroxyproline excretion in the case of G.H. may be related to a weight gain of $4 \mathrm{~kg}$ over the 3 week period.

Four of the subjects from this group were placed on the low protein diet for 3 days after completing 3 to 6 weeks on the low hydroxyproline diet. There was no further change in their hydroxyproline excretions (Table I, column 3 ). Two normal subjects (A.F. and R.A.) were placed on the low protein diet after 3 weeks' observation on ad lib. diet. As shown in Table II, the hydroxyproline excretion remained constant

TABLE I

Failure of low hydroxyproline diet and low protein diet to decrease hydroxyproline excretion *

\begin{tabular}{|c|c|c|c|c|c|c|}
\hline \multirow[b]{2}{*}{ Subject } & \multicolumn{2}{|c|}{ Ad lib. diet } & \multicolumn{2}{|c|}{$\begin{array}{l}\text { Low hydroxyproline } \\
\text { diet 3-6 weeks }\end{array}$} & \multicolumn{2}{|c|}{ Low protein diet 3 days } \\
\hline & $\begin{array}{c}\text { Free } \\
\text { hydroxy. }\end{array}$ & $\begin{array}{c}\text { Bound } \\
\text { hydroxy. }\end{array}$ & $\begin{array}{c}\text { Free } \\
\text { hydroxy. }\end{array}$ & $\begin{array}{c}\text { Bound } \\
\text { hydroxy. }\end{array}$ & $\begin{array}{c}\text { Free } \\
\text { hydroxy. }\end{array}$ & $\begin{array}{c}\text { Bound } \\
\text { hydroxy. }\end{array}$ \\
\hline J.R. & $<1.0$ & $\begin{array}{l}y \\
(23-31) \dagger\end{array}$ & $<1.0$ & $\begin{array}{c}30 \\
(24-36)\end{array}$ & $<1.0$ & $\begin{array}{cc}y & 37 \\
& (28-42)\end{array}$ \\
\hline K.L. & $<1.0$ & $\begin{array}{c}32 \\
(30-34)\end{array}$ & $<1.0$ & $\begin{array}{c}46 \\
(44-51)\end{array}$ & $<1.0$ & $\begin{array}{c}46 \\
(43-48)\end{array}$ \\
\hline G.H. & $<1.0$ & $\begin{array}{c}21 \\
(16-29)\end{array}$ & $<1.0$ & $\begin{array}{c}16 \\
(13-22)\end{array}$ & $<1.0$ & $\begin{array}{c}14 \\
(13-15)\end{array}$ \\
\hline R.F. $\ddagger$ & $<1.0$ & $\begin{array}{c}62 \\
(46-88)\end{array}$ & $<1.0$ & $\begin{array}{c}61 \\
(42-92)\end{array}$ & $<1.0$ & $\begin{array}{c}64 \\
(59-69)\end{array}$ \\
\hline R.B. $\ddagger$ & $<1.0$ & $\begin{array}{c}39 \\
(38-40)\end{array}$ & $<1.0$ & $\begin{array}{c}38 \\
(33-43)\end{array}$ & & \\
\hline B.F. $\ddagger$ & $<1.0$ & $\begin{array}{c}77 \\
(63-91)\end{array}$ & $<1.0$ & $\begin{array}{c}79 \\
(75-84)\end{array}$ & & \\
\hline
\end{tabular}

* Values for free and bound hydroxyproline are means of five 24-hour excretions on the ad lib. or low hydroxyproline diet and the means of three 24-hour excretions on the low protein diet.

t Figures in parentheses are the range of bound hydroxyproline excretions. $\ddagger$ Marfan’s syndrome. 
TABLE II

Effect of low protein diet on hydroxyproline, total nitrogen, and $\alpha$-amino nitrogen excretion

\begin{tabular}{|c|c|c|c|c|c|c|}
\hline \multirow[b]{2}{*}{ Diet } & \multicolumn{2}{|c|}{ Total hydroxy. } & \multicolumn{2}{|c|}{ Total nitrogen } & \multicolumn{2}{|c|}{$\alpha$-Amino nitrogen } \\
\hline & J.B. & R.A. & J.B. & R.A. & J.B. & R.A. \\
\hline & \multicolumn{2}{|c|}{$m g / d a y$} & \multicolumn{2}{|c|}{$g_{/}^{\prime} d a y$} & \multicolumn{2}{|c|}{$g / d a y$} \\
\hline Ad lib. & $\begin{array}{l}31.7 \\
25.2 \\
27.4\end{array}$ & $\begin{array}{l}32.7 \\
27.1 \\
29.2\end{array}$ & $\begin{array}{l}6.51 \\
8.96 \\
9.35\end{array}$ & $\begin{array}{l}14.88 \\
13.38 \\
14.65\end{array}$ & $\begin{array}{l}1.11 \\
2.25 \\
1.48\end{array}$ & $\begin{array}{l}3.48 \\
3.38 \\
3.24\end{array}$ \\
\hline $\begin{array}{l}\text { Low hydroxy- } \\
\text { proline }\end{array}$ & $\begin{array}{l}23.9 \\
20.2 \\
27.6\end{array}$ & $\begin{array}{l}33.1 \\
26.2 \\
39.9\end{array}$ & $\begin{array}{r}6.58 \\
6.22 \\
10.24\end{array}$ & $\begin{array}{l}10.56 \\
11.93 \\
11.80\end{array}$ & $\begin{array}{l}2.16 \\
2.07 \\
1.21\end{array}$ & $\begin{array}{l}3.66 \\
3.00 \\
3.92\end{array}$ \\
\hline Low protein & $\begin{array}{l}27.4 \\
26.1 \\
28.2\end{array}$ & $\begin{array}{l}26.1 \\
29.0 \\
31.3\end{array}$ & $\begin{array}{l}5.16 \\
4.43 \\
3.86\end{array}$ & $\begin{array}{l}8.88 \\
5.33 \\
4.67\end{array}$ & $\begin{array}{l}1.08 \\
1.09 \\
0.47\end{array}$ & $\begin{array}{l}1.41 \\
1.85 \\
2.32\end{array}$ \\
\hline
\end{tabular}

even though the low protein diet produced a decrease in the excretion of both urinary total nitrogen and $\alpha$-amino nitrogen.

Diurnal pattern of hydroxyproline excretion. To investigate any possible diurnal variations in the rate of hydroxyproline excretion, urine was collected by 6-hour periods on 2 consecutive days from two normal subjects and one patient with Marfan's syndrome, while all three subjects were on the low hydroxyproline diet (Table III). There was no consistent pattern in the amount of hydroxyproline excreted, and there were no apparent changes with daytime activities or with meals (served at 8 a.m., 1 p.m. and 5 p.m.).

Effect of hydration and dehydration. To determine the influence of moderate water diuresis on the renal excretion of hydroxyproline, two normal subjects were placed on the low hydroxyproline diet and their urine collected from 8 a.m. to 4 p.m. for 9 consecutive days. On 3 control days the subjects were allowed free access to water. During 3 days of hydration they were given an additional $500 \mathrm{ml}$ water at midnight, $500 \mathrm{ml}$ at

TABLE III

Diurnal pattern of hydroxyproline excretion ( $\mathrm{mg} / 6$ hours)

\begin{tabular}{lrrrr}
\hline & $\begin{array}{c}\text { 6 a.m.- } \\
12 \text { m. }\end{array}$ & $\begin{array}{r}\text { 12 m.- } \\
\text { 6 p.m. }\end{array}$ & $\begin{array}{c}\text { 6 p.m.- } \\
\text { 12 mid. }\end{array}$ & $\begin{array}{c}\text { 12 mid.- } \\
\text { 6 a.m. }\end{array}$ \\
\hline A.F. & 10.6 & 6.7 & 8.4 & 8.2 \\
& 10.0 & 12.9 & 7.4 & 4.8 \\
R.A. & 8.5 & 5.8 & 12.2 & 7.1 \\
& 7.9 & 14.7 & 7.0 & 7.8 \\
R.F.* & 19.7 & 16.6 & 22.2 & 22.0 \\
& 17.1 & 17.8 & 33.6 & 19.3
\end{tabular}

\footnotetext{
* Marfan's syndrome.
}

the start of the collection, and $500 \mathrm{ml}$ at 12 noon. On the final 3 days of the study the daily total fluid intake was limited to $500 \mathrm{ml}$. As shown in Table IV, there was no consistent change in hydroxyproline excretion with threefold changes in urine volumes.

Effect of hydroxyproline and gelatin ingestion. Ziff and associates (1) found that no increase in total urinary hydroxyproline occurred when the low hydroxyproline diet was supplemented with $4 \mathrm{~g}$ of hydroxy-L-proline. However, a four- to fivefold increase was observed when gelatin containing an equivalent amount of hydroxyproline was administered.

In repeating the experiments, we were also unable to demonstrate any significant increase in total urinary hydroxyproline after administration of 4 $\mathrm{g}$ of hydroxy-L-proline (Figure 1). There was, however, a significant increase in free hydroxyproline (from less than $1 \mathrm{mg}$ per day to 5 to 16 $\mathrm{mg}$ ) in four subjects tested. A fifth subject, K.L. (Figure 2) showed no change. When the diet was supplemented with $12 \mathrm{~g}$ of hydroxy-L-proline, there were dramatic increases in the urinary free hydroxyproline in all eight subjects tested; the increases shown in Figure 1 are typical. It is important to note that, within the limits of the analyses, there were no changes in the excretion of bound hydroxyproline. Furthermore, there was no increase in bound hydroxyproline when the same subjects were given a synthetic mixture of the amino acids found in gelatin (Figure 1, column 4). In contrast, when $28 \mathrm{~g}$ of gelatin (containing $4 \mathrm{~g}$ of hydroxyproline) was given, the increase in urinary hydroxyproline was al- 
TABLE IV

Failure of hydration and dehydration to influence hydroxyproline excretion (see text)

\begin{tabular}{lccccc}
\hline & \multicolumn{2}{c}{ Subject } & A.F. & & \multicolumn{2}{c}{ Subject J.B. } \\
\cline { 2 - 3 } \cline { 5 - 6 } Period & $\begin{array}{c}\text { Urine } \\
\text { vol }\end{array}$ & Hydroxy. & & $\begin{array}{c}\text { Urine } \\
\text { vol }\end{array}$ & Hydroxy. \\
\cline { 5 - 6 } Control & $m l$ & $m g / 8$ hrs & & $m l$ & $m g / 8$ hrs \\
& 985 & 9.7 & & 780 & 8.4 \\
& 620 & 9.4 & & 920 & 6.5 \\
Hydration & 1,000 & 10.1 & & 840 & 6.6 \\
& 1,470 & 9.5 & & 1,580 & 10.5 \\
& 1,560 & 12.5 & 1,390 & 8.7 \\
Dehydration & 1,620 & 10.0 & & 1,650 & 9.0 \\
& 250 & 11.5 & & 380 & 10.5 \\
& 500 & 10.2 & 410 & 12.5 \\
& 490 & 9.2 & 475 & 7.7 \\
& & & & &
\end{tabular}

most entirely in the peptide-bound fraction (Figure 1 , column 5). Five $g$ of gelatin did not change free or bound hydroxyproline in the same subjects. Two normal subjects (J. B. and G. H.) were given $100 \mathrm{~g}$ of gelatin in a single dose. Their free hydroxyproline excretion rose from less than $1 \mathrm{mg}$ per day to. 200 and $300 \mathrm{mg}$, respectively. Simultaneously, their bound hydroxy- proline rose from mean values of 25 and $39 \mathrm{mg}$ to 356 and $427 \mathrm{mg}$.

Throughout this study there was no consistent difference between the response of normal subjects and patients with Marfan's syndrome to the feeding of gelatin or free hydroxyproline.

Effect of other amino acids on excretion of hydroxyproline. In examining the results shown in Figure 1, it is seen that more free hydroxyproline was excreted by all four subjects when $4 \mathrm{~g}$ of hydroxy-L-proline was given with a mixture of the amino acids found in gelatin than when $4 \mathrm{~g}$ of hydroxy-L-proline was ingested alone. To explore the significance of this finding, hydroxy-Lproline was given to four subjects with hydrolyzed casein and with individual amino acids (Figure 2). All four excreted more hydroxyproline when the imino acid was given with the hydrolyzed casein than when it was administered alone, but the change in one instance (K.L.) was small. When hydroxyproline was given with proline or glutamic acid, a similar increase in the amount ex-

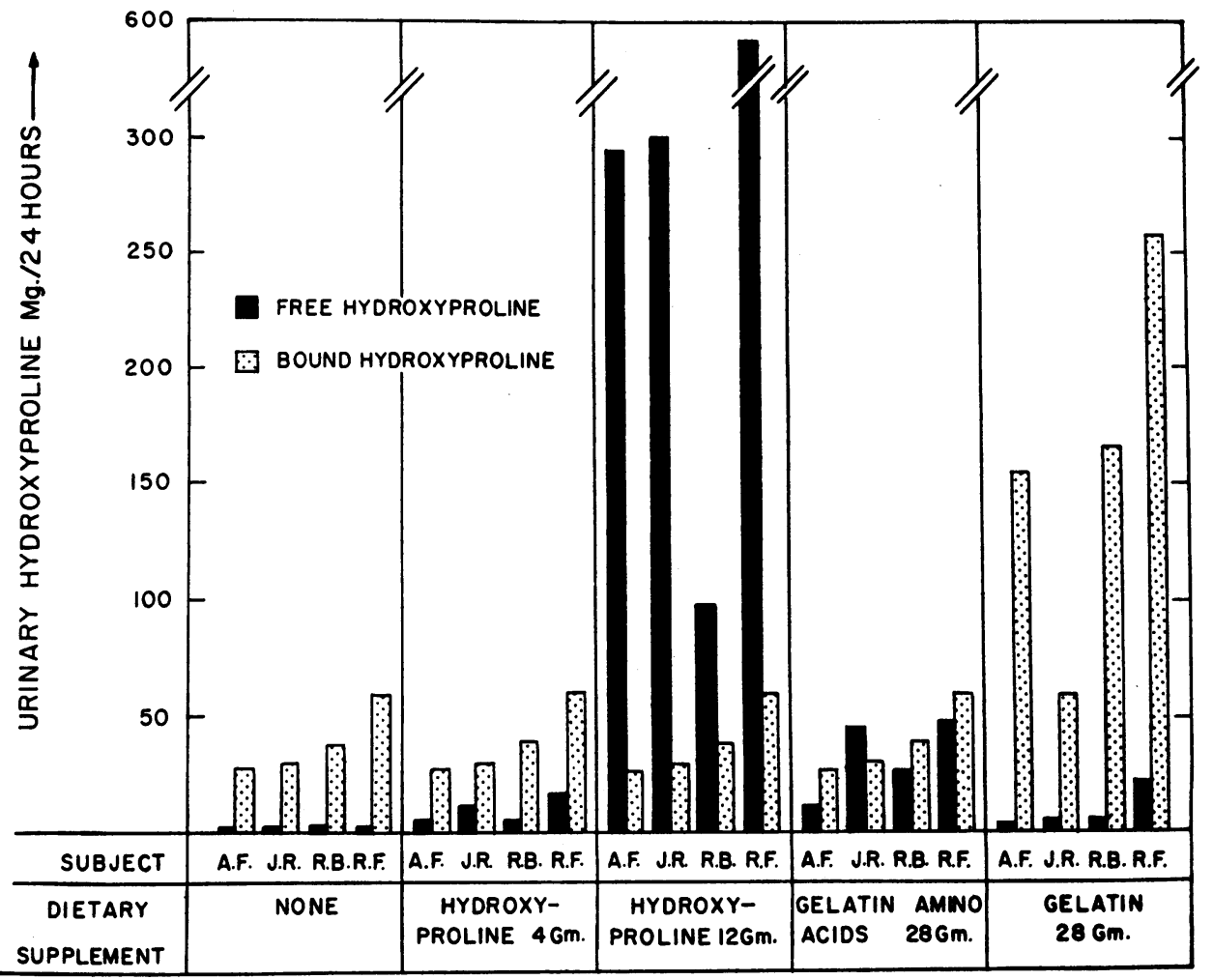

FIG. 1. EFFECT OF HYDROXYPROLINE AND GELATIN INGESTION ON THE EXCRETION OF FREE AND BOUND HYDROXYPROLINE. "Gelatin amino acids" was a prepared mixture of the amino acids found in gelatin (5). Patients R.B. and R.F. had Marfan's syndrome. 


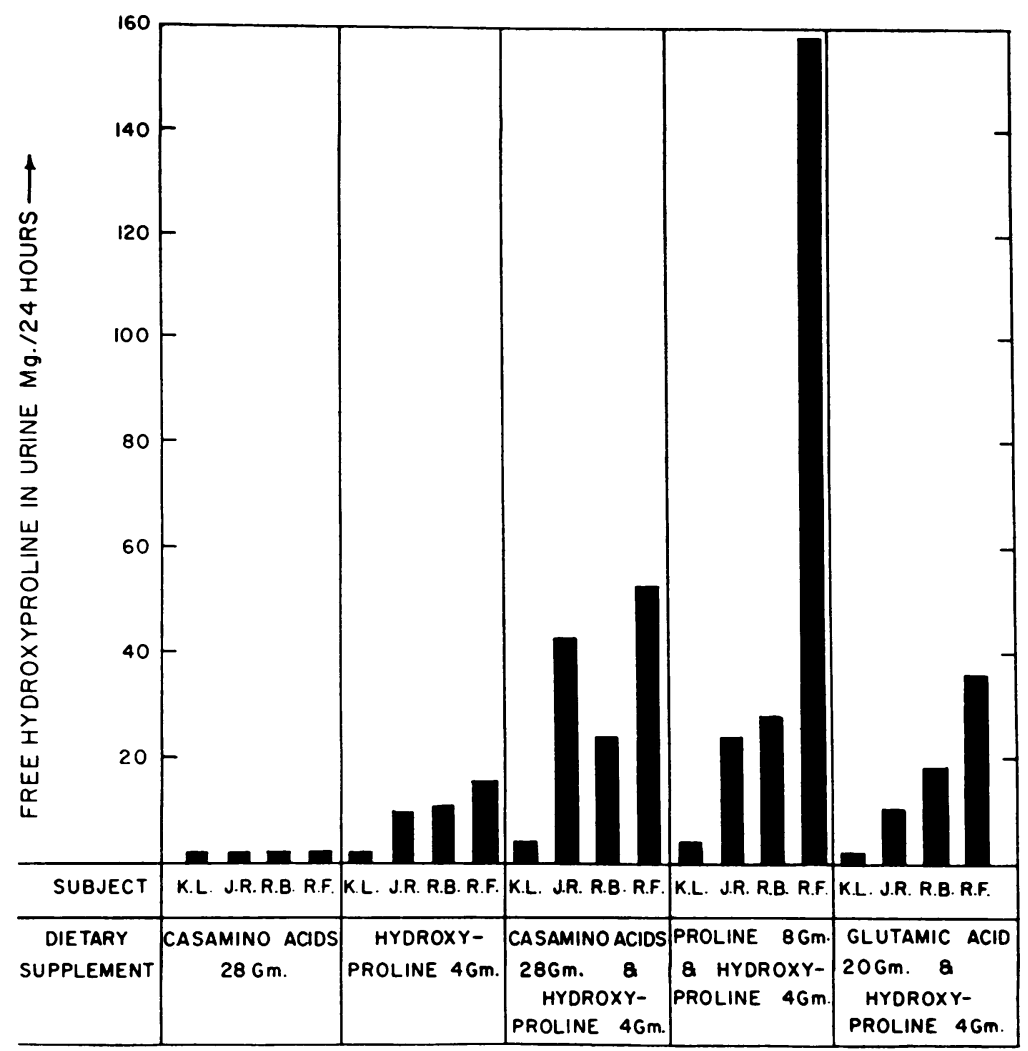

Fig. 2. EFfect of hydroxyproline and amino acid mixtures on the EXCRETION OF FREE AND BOUND Hydroxyproline. Patients R.B. and R.F. had Marfan's syndrome.

creted occurred in three of the four subjects (Figure 2). The administration of proline, glutamic acid or hydrolyzed casein alone did not alter hydroxyproline excretion.

\section{DISCUSSION}

Currently available evidence indicates that bound hydroxyproline, the form which predominates in human urine, consists of hydroxyproline peptides. Westall (11) described a peptide in human urine containing equal amounts of proline and hydroxyproline, and Mechanic, Skupp, Safier and Kibrick (12) recently determined the amino acid composition of two hydroxyproline peptides in the urine of a patient with rheumatoid arthritis.

Since collagen contains nearly all of the hydroxyproline in the body, the hydroxyproline found in urine could arise from three possible sources: from dietary hydroxyproline, from precursors involved in the synthesis of collagen, or from peptides released by the breakdown of collagen.

Although ingestion of large amounts of gelatin results in increased hydroxyproline excretion (1), dietary hydroxyproline is not an important source of urinary hydroxyproline. Ziff and associates (1) found that patients on diets containing less than $100 \mathrm{mg}$ of hydroxyproline excreted 20 to $40 \mathrm{mg}$ of the imino acid per day. Similarly, it was found here (Table I) that there was no significant decrease in urinary hydroxyproline as subjects were changed from a normal to a low hydroxyproline diet, and finally to a diet that was virtually free of hydroxyproline.

At the present time there is little evidence to suggest that urinary hydroxyproline comes from hydroxyproline peptides which are precursors in collagen synthesis. Ziff and associates (1) considered the possibility that the increased excretion of hydroxyproline peptides in children is the result of an increased pool of hydroxyproline pep- 
tide "available for collagen synthesis." According to current concepts, however, exchangeable pools of peptides do not play an important role in protein synthesis, and the synthesis of hydroxyproline peptides has not yet been demonstrated. The failure of the low protein diet to decrease hydroxyproline excretion (Tables I and II) also makes it unlikely that urinary hydroxyproline peptides represent collagen precursors. The subjects on the low protein diet received less than 0.5 $g$ of nitrogen per day and were in negative nitrogen balance even though their caloric intake was normal. Under these conditions there is a general decrease of protein synthesis (13), and one would expect a decrease of hydroxyproline excretion if urinary hydroxyproline arises from pools of collagen precursors.

The results presented here therefore support the hypothesis that urinary hydroxyproline arises primarily from the breakdown of body collagen. It is of interest that the composition of the peptides studied by Mechanic and co-workers (12) is not consistent with the known amino acid sequences of collagen (14). The reason for this is not clear, and a full explanation will probably have to wait for a complete understanding of the structure of collagen. The pepticles may be altered after release from collagen, or possibly may represent ester-bonded fragments which result from transverse cleavage of the 3 -stranded helical structure postulated for collagen $(15,16)$.

If it is accepted that urinary hydroxyproline arises primarily from body collagen, then at least three factors might be expected to influence the amount of hydroxyproline excreted: the rate of plasma clearance by the kidneys, the rate at which hydroxyproline peptides are degraded further to carbon dioxide and urea, and the rate of collagen breakdown.

There is no evidence to suggest that variations in renal clearance are important in determining the amount of hydroxyproline excreted. Children excrete three to five times as much hydroxyproline as do adults, even though total amino acid excretion is less in children (1). Similarly, some patients with Marfan's syndrome excrete three to four times as much hydroxyproline as do controls, but their total amino acid excretion is normal (2). The excretion of free hydroxyproline was potentiated by the simultaneous feeding of proline or glutamic acid (Figure 2), prubably because of competition for the same reabsorption mechanism in the renal tubules. Kamin and Handler (17) reported similar results with the infusion of other amino acids in dogs. There may be other explanations for our results here, but at any rate the large amounts of amino acids necessary to demonstrate the effect make it unlikely that this mechanism normally has much influence on urinary hydroxyproline. It was not possible to test directly for any effect which other peptides may have on the excretion of bound hydroxyproline, but it was shown that endogenous hydroxyproline excretion was not increased following meals (Table III) and that the excretion of hydroxyproline was not related to the rate of urine formation (Table IV).

At the moment it is impossible to estimate the degree to which hydroxyproline peptides from collagen breakdown are metabolized to carbon dioxide and urea. Although these are the major products from the degradation of other proteins (18), several observations suggest that the degradation of collagen hydroxyproline is not complete. The studies of Stetten and Schoenheimer (19) indicate that hydroxyproline does not share in the same "dynamic equilibrium" as other amino acids. The results with the low protein diet (Table II) support this conclusion and show that hydroxyproline excretion is not influenced by the same factors that influence the excretion of other amino acids. Since it has been shown that only minimal amounts of peptides are absorbed during protein digestion (20), the increase of bound hydroxyproline excretion after the ingestion of gelatin (Figure 1) raises the possibility that all of the hydroxyproline peptides absorbed were excreted in the urine. These exogenous peptides may be altered before excretion (12), but the results suggest that they are metabolized slowly, if at all. The same may be true for endogenous ones, but the situation may vary in different tissues (21).

If a relatively small part of the hydroxyproline from collagen degradation is metabolized to carbon dioxide and urea, then hydroxyproline excretion should be directly related to the rate of collagen breakdown. Studies on collagen metabolism in animals are consistent with this hypothesis, since hydroxyproline excretion decreases with age (1) and the turnover rate of collagen is much 
slower in old animals than in young (22). As discussed by Ziff and associates (1), these differences may be related to the decrease of the various soluble collagens in old animals (23) and suggest that the amount of hydroxyproline found in urine directly reflects the proportion of body collagen in a soluble form. The increased hydroxyproline excretion in some cases of Marfan's syndrome may therefore indicate increased amounts of soluble collagen and a rapid rate of collagen breakdown in this condition. We are currently undertaking experiments to test this hypothesis further.

\section{SUM MARY}

Several factors that might affect the urinary excretion of hydroxyproline were studied in five normal subjects and in three patients with Marfan's syndrome.

Urinary excretion of hydroxyproline did not decrease when subjects were changed from a normal to a low hydroxyproline diet, or to an isocaloric low protein diet. No diurnal variation in urinary hydroxyproline was found, and hydration or dehydration did not alter excretion.

Ingestion of hydroxyproline as the free imino acid resulted in an increased excretion of free hydroxyproline, but no change in the excretion of bound hydroxyproline, the peptide form which normally accounts for nearly all of the hydroxyproline in urine. Ingestion of large amounts of hydroxyproline in the form of gelatin, however, increased the excretion of hydroxyproline peptides.

The findings suggest that the bound hydroxyproline normally found in urine arises from collagen breakdown and that the amount excreted is an index of the rate of degradation of this protein.

\section{REFERENCES}

1. Ziff, M., Kibrick, A., Dresner, E., and Gribetz, H. J. Excretion of hydroxyproline in patients with rheumatic and non-rheumatic diseases. J. clin. Invest. 1956, 35, 579.

2. Sjoerdsma, A., Davidson, J. D., Udenfriend, S., and Mitoma, C. Increased excretion of hydroxyproline in Marfan's syndrome. Lancet 1958, 2, 994.

3. Stetten, M. R. Some aspects of the metabolism of hydroxyproline, studied with the aid of isotopic nitrogen. J. biol. Chem. 1949, 181, 31.

4. Block, R. J., and Weiss, K. W. Amino Acid Handbook; Methods and Results of Protein Analysis. Springfield, Ill., C. C Thomas, 1956, p. 346.

5. Ibid., p. 274.
6. Mitoma, C., Smith, T. E., Davidson, J. D., Udenfriend, S., DaCosta, F. M., and Sjoerdsma, A. Improvements in methods for measuring hydroxyproline: Application to human urine. J. Lab. ciin. Med. 1959, 53, 970.

7. Prockop, D. J., and Udenfriend, S. A simple method for the analysis of hydroxyproline in tissues and urine. Analyt. Biochem. 1960, 1, 228.

8. Hawk, P. B., Oser, B. L., and Summerson, W. H. Practical Physiological Chemistry, 13th ed. New York, Blakiston, 1954, p. 874.

9. Troll, W., and Cannan, R. K. A modified photometric ninhydrin method for the analysis of amino and imino acids. J. biol. Chem. 1953, 200, 803.

10. Gross, J. Studies on the formation of collagen. II. The influence of growth rate on neutral salt extracts of guinea pig dermis. J. exp. Med. 1958, 107, 265.

11. Westall, R. G. The amino acids and other ampholytes of urine. Three unidentified substances excreted in normal human urine. Biochem. J. 1955, $60,247$.

12. Mechanic, G., Skupp, S. J., Safier, L. B., and Kibrick, A. C. Isolation of two peptides containing hydroxyproline from urine of a patient with rheumatoid arthritis. Arch. Biochem. 1960, 86, 71.

13. West, E. S., and Todd, W. R. Textbook of Biochemistry, 2nd ed. New York, Macmillan, 1955, p. 1161.

14. Kroner, T. D., Tabroff, W., and McGarr, J. J. Peptides isolated from a partial hydrolysate of steer hide collagen. II. Evidence for the prolyl-hydroxyproline linkage in collagen. J. Amer. chem. Soc. 1955, 77, 3356.

15. Rich, A., and Crick, F. H. The structure of collagen. Nature (Lond.) 1955, 176, 915.

16. Mechanic, G. L., and Levy, M. An $\epsilon$-lysine tripeptide obtained from collagen. J. Amer. chem. Soc. 1959, 81, 1889.

17. Kamin, H., and Handler, P. Effect of infusion of single amino acids upon excretion of other amino acids. Amer. J. Physiol. 1951, 164, 654.

18. West, E. S., and Todd, W. R. Textbook of Biochemistry, 2nd ed. New York, Macmillan, 1955, p. 1242.

19. Stetten, M. R., and Schoenheimer, R. The metabolism of 1 (-)-proline studied with the aid of deuterium and isotopic nitrogen. J. biol. Chem. 1944, 153, 113.

20. Crane, C. W., and Neuberger, A. The digestion and absorption of protein by normal man. Biochem. J. 1960, 74, 313.

21. Woessner, J. F., Jr. Collagen degradation in involuting uterus. Fed. Proc. 1959, 18, 461.

22. Neuberger, A., Perrone, J. C., and Slack, H. G. B. The relative metabolic inertia of tendon collagen in the rat. Biochem. J. 1951, 49, 199.

23. Kao, K. T., and McGavack, T. H. Connective tissue: I. Age and sex influence on protein composition of rat tissues. Proc. Soc. exp. Biol. (N. Y.) 1959, 101, 153. 